\title{
Biological systems for the protection of spring rapeseed from pests as a promising direction for a production increase of environmentally friendly and competitive oilseeds in the Republic of Tatarstan
}

\author{
Salavat Suleimanov, Ravil Safiollin, Nikolay Loginov, Lilia Vafina \\ Kazan Agricultural State University, 65, K. Marx Street, Kazan, the Republic of Tatarstan, 420015, Russia
}

\begin{abstract}
This paper presents the ideas of the authors, confirmed by the results of a stationary field experiment on the possibility of widespread use of modern biological products of insecticidal action in the system of protection of the main oilseed crop of the Republic of Tatarstan namely spring rapeseed from such most harmful objects as cruciferous flea, cabbage moth, rape sawfly, flower beetle, secretive proboscis etc. The stationary field experiments were carried out on the basis of the agrarian biological technological park of Kazan State Agrarian University. The laboratory analyzes were carried out at the center of agroecological research of the agronomic faculty. The soils of the experimental site were gray forest, with the following agrochemical indicators: the content of humus according to Tyurin was 3.0\%, mobile phosphorus was high (160 mg / kg) and exchangeable potassium was increased (145 mg/kg according to Kirsanov). The objects of research were the crops of spring rape of the Ruyan variety named after V.S. Pustovoyta, biological preparations Nodix Premium, Nodix Insectobact and Nodix Biofungicide. The importance of these studies is explained by the fact that in recent years, the number and resistance of pests of spring rape to chemical insecticides has increased and, accordingly, the chemical load on the environment has also increased. In this regard, the study of promising insecticides of biological origin on spring rape is an urgent task. During the research, it was found that the pre-sowing treatment of seeds with Insectobact $(11 / \mathrm{t}$ of seeds) in combination with a nutrient solution Nodix Premium $(0.31 / \mathrm{t})$ in terms of the effectiveness of suppressing cruciferous flea bees is equivalent to dressing the seed with a chemical dressing agent Cruiser Rape $(151 / t)$. t). Moreover, a significant reduction in the chemical load on the environment ensures the use of the same biological products against other pests during the growing season of plants.
\end{abstract}

\section{Introduction}

The protection of rapeseed raw materials from more than 80 pests was and remains the weakest point in the production of this crop [1-3].

Thus, in recent years, due to hot dry May, the cabbage moth, despite 3-4 times insecticidal treatment, have caused unprecedented damage to the yield of the object of our research.

At the same time, the shortage of thermal resources in the summer months becomes the cause of mass destruction of plants by lurkers and rape sawflies $[4,5]$.

In this regard, the most important problem in the technology of cultivation of spring rape is the development of a highly effective system to protect plants from pests, including biological control measures. Therefore, the purpose of the research is a comparative assessment of the effectiveness of the action of chemical and biological preparations of insecticidal action against the main pests of the studied crop.
In order to achieve this purpose, it was necessary to solve the following tasks:

1. To determine the dynamics of the accumulation of pests by options of experience.

2. To establish the influence of the studied systems of protection of spring rapeseed on the safety of plants for harvesting.

3. To reveal the effectiveness of the interaction of fertilizer-stimulating compositions and biological products of insecticidal action on the basis taking into account yield, crude fat content and gross harvest of rapeseed vegetable oil.

4. To develop specific proposals aimed to reduce the chemical load on the environment in the production of environmentally friendly competitive rapeseed oilseed raw materials.

\section{Research methods}

The stationary field experiments were carried out based on the agrarian biological technological park of Kazan

$\overline{\text { *Corresponding author: dusai@mail.ru }}$ 
State Agrarian University with location coordinates: 55.5244865824 and longitude - 48.274901646, and laboratory analyzes were carried out at the center of agroecological research of the agronomic faculty.

The object of research was the variety of spring rape Ruyan named after V.S. Pustovoit, which was approved for cultivation in 2015 in the Central, Volga-Vyatka, North Caucasian and Ural regions of the Russian Federation [6].

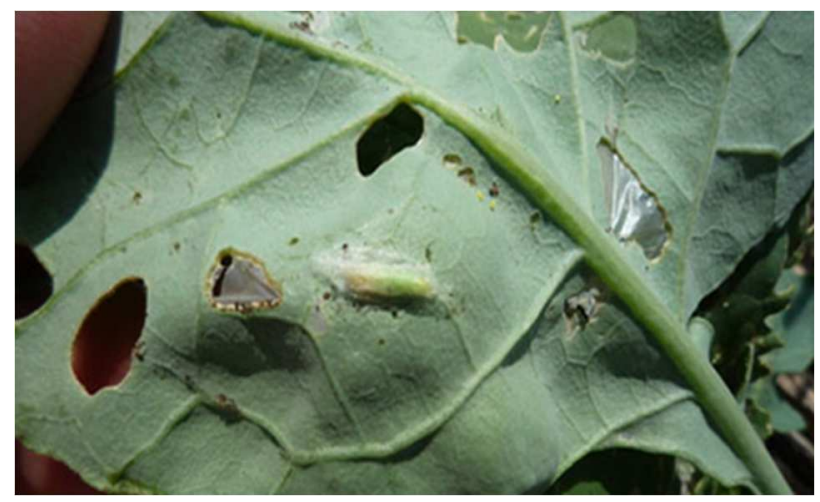

Fig. 1. Cruciferous flea and its action

A variety of two zero types (OO) with a minimum content of glucosinolates and erucic acid the MAC of which is close to zero. The field experiments were carried out on typical gray forest soils with the following agrochemical indicators: the content of humus according to Tyurin was $3.0 \%$, mobile phosphorus was high (160 $\mathrm{mg} / \mathrm{kg}$ ) and exchangeable potassium was increased (145 $\mathrm{mg} / \mathrm{kg}$ according to Kirsanov).

The reaction of the soil environment was close to neutral ( $\mathrm{pH}$ 6.6). Taking into account the content of nutrients, ammonium nitrate phosphate fertilizer (N16 P16 K16) was added for pre-sowing cultivation and ammonium nitrate $100 \mathrm{~kg} / \mathrm{ha}$ in the physical mass was used for feeding in the phase of 3-4 leaves of spring rape (the average background of mineral nutrition of spring rape in the Republic of Tatarstan).

Agrometeorological conditions during the years of the research differed from the average long-term indicators in that the end of May - the beginning of June were hot and dry (precipitation was only $4 \%$ of the norm), and the first half of July was cold and rainy. In this regard, at the beginning of June, there were ideal conditions for mass destruction of crops by the cabbage moth, and in July - by snout beetle, sawfly and flower beetle. In the field studies, spring rape was placed after winter wheat, which served as an equalizing crop. The technology and methodology for conducting the field experiment were generally accepted.

\section{Results and discussion}

The dynamics of the accumulation of pests. Presowing seed treatment with the chemical seed dressing Cruiser Rape $(15 \mathrm{l} / \mathrm{t})$ provided reliable protection of spring rape seedlings from cruciferous flea beetles, since their total number was 1.2 pcs/plant with an established severity threshold of 2-3 pcs/plant. An option of the experiment with pre-sowing seed treatment with Insectobact at the rate of $11 / \mathrm{t}$ in combination with Nodix Premium $(0.51 / t)$ also meth this requirement as well as additional treatment of plants in the rosette phase with the same preparations 0.3 and 21 / ha, respectively.

Under the same conditions, a decrease in the consumption rates of these biological products or their replacement with Rizoplan becomes the reason for an excess of the number of cruciferous flea beetles by 2.03.5 times compared to the control and the complete destruction of cotyledon leaves from 8 to $19 \mathrm{pcs} / \mathrm{m}^{2}$.

Snout beetle also does harm to the crops of spring rapeseed, penetrating inside the stem, literally eats the branching node, usually the central, most productive rapeseed branch (Fig. 2).

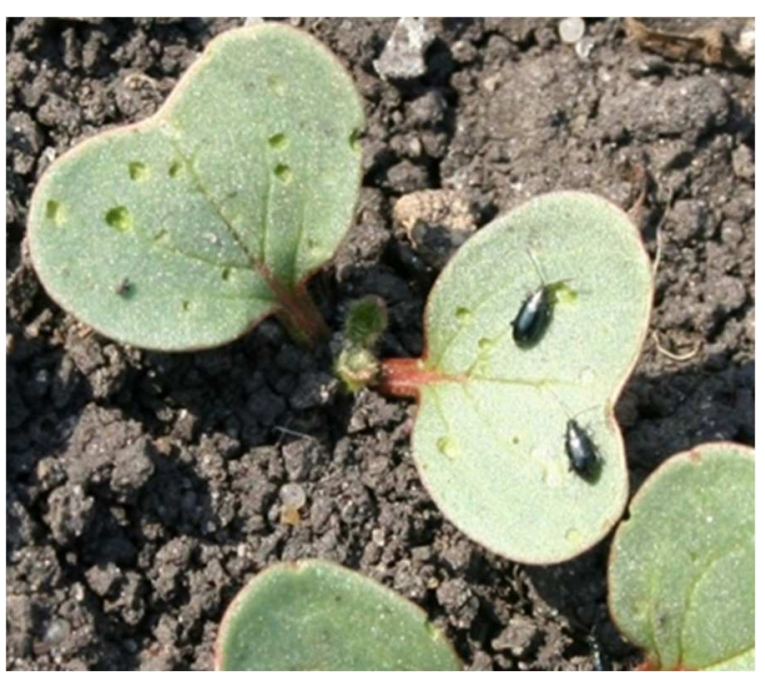

Fig. 2. Cabbage moth and its action

For example, the difference in favor of Insectobact in comparison with Rizoplan was from 55 to $84 \%$, although the effectiveness of its action was inferior to the traditional pre-sowing preparation of seeds with the chemical seed dressing Cruiser Rape.

In conclusion, it is necessary to note the importance of two-fold application of the fertilizing biological product Nodix Premium, which accelerates the growth and development of lateral branches of spring rape, the pods on which reach harvest ripeness.

Due to the significant climate warming, the cabbage moth becomes the most dangerous pest of this culture [7, 8]. Thus, the end of May and the beginning of June of the last two years were absolutely dry and hot. The number of cabbage moth in all options of the experiment was several times higher than the threshold values (2-3 caterpillars/plant).

On the other hand, the situation is complicated by the fact that by this time the effect of the studied chemical and biological disinfectants is almost reduced to zero. Since the cabbage moth eats the leaf pulp from the underside, the crops of spring rape become white $[9,10]$.

Therefore, in ordinary farms, crops of spring rape are treated with contact-intestinal insecticides at least 3 times as in the first two options of our experiment (Table $1)$. 
Three times spraying with various chemical insecticides in the control option of the experiment ensured a decrease in the amount of cabbage moth from 10.4 to $3.6 \mathrm{pcs} / \mathrm{plant}$, and in the second option with presowing seed treatment with Rizoplan it ensured a decrease from 15.6 to 6.8 .

In the remaining options of the experiment, exceeding the harmfulness threshold of the cabbage moth more than 3 times, it was decided to carry out the treatment with biological products according to the experiment scheme, but in combination with the Break insecticide, which allowed minimizing the damage to the cabbage moth, especially with the Insectobact consumption rate of 2 liters/ha with the addition of Nodix Premium 0.3 1/ha (3.8 pcs / plant).

Due to the use of biological agents of insecticidal action in combination with foliar feeding of plants Nodix Premium, it is possible to achieve very high results in the fight against one of the most dangerous pests - the rape flower beetle (Table 2)

Table 1. Impact of cabbage moth crops on spring rape by experimental options, pcs/plant (2019-2020)

\begin{tabular}{|c|c|c|c|c|}
\hline \multirow{2}{*}{ Option } & \multirow{2}{*}{$\begin{array}{c}\text { Before } \\
\text { treatment }\end{array}$} & \multirow{2}{*}{$\begin{array}{c}\text { After } \\
\text { treatment }\end{array}$} & \multicolumn{2}{|c|}{$\begin{array}{l} \pm \text { to the first } \\
\text { control }\end{array}$} \\
\hline & & & pcs/plant & $\%$ \\
\hline Control (Standard chemical technology) & 10,4 & 3,6 & - & - \\
\hline Control 2 (Standard biological product Rizoplan) & 15,6 & 6,8 & 3,2 & 112 \\
\hline $\begin{array}{l}\text { Seed treatment with Nodix Premium, } 0.11 / \mathrm{t} \text { of seeds }+ \text { Nodix } \\
\text { Insectobact } 0.51 / \mathrm{t} \text { of seeds; Spraying in the bud phase with Nodix } \\
\text { Premium, } 0.31 / \text { ha }+ \text { Nodix Insectobact } 0.51 / \text { ha; Spraying in the } \\
\text { phase of bud formation with Nodix Premium, } 0.11 / \text { ha }\end{array}$ & 13,2 & 5,5 & 1,9 & 53 \\
\hline $\begin{array}{l}\text { Seed treatment with Nodix Premium, } 0.31 / \mathrm{t} \text { of seeds }+ \text { Nodix } \\
\text { Insectobact } 11 / \mathrm{t} \text { of seeds; Spraying in the bud phase with Nodix } \\
\text { Premium, } 0.31 / \text { ha }+ \text { Nodix Insectobact } 1.01 / \text { ha; Spraying in the } \\
\text { phase of bud formation with Nodix Premium, } 0.11 / \text { ha; Spraying in } \\
\text { the filling phase with Nodix Biofungicide } 1.01 / \text { ha. }\end{array}$ & 12,4 & 4,9 & 1,3 & 36 \\
\hline $\begin{array}{l}\text { Seed treatment with Nodix Premium, } 0.51 / \mathrm{t} \text { of seeds }+ \text { Nodix } \\
\text { Insectobact } 11 / \mathrm{t} \text { of seeds; Spraying in the bud phase with Nodix } \\
\text { Premium, } 0.31 / \text { ha }+ \text { Nodix Insectobact } 2.01 / \text { ha; Spraying in the } \\
\text { phase of bud formation with Nodix Premium, } 0.11 / \text { ha }+ \text { Nodix In- } \\
\text { sectobact } 2.01 / \mathrm{ha} \text {; Spraying in the filling phase with Nodix } \\
\text { Biofungicide } 1.0 \mathrm{l} / \mathrm{ha} \text {. }\end{array}$ & 11,7 & 3,8 & 0,2 & 6 \\
\hline
\end{tabular}

Table 2. Comparative assessment of the effectiveness of insecticidal and biological treatment of crops against rape flower beetle on average for 2 years (pcs/plant)

\begin{tabular}{|c|c|c|c|c|}
\hline \multirow{2}{*}{ Option } & \multirow{2}{*}{$\begin{array}{c}\text { Before } \\
\text { treatment }\end{array}$} & \multirow{2}{*}{$\begin{array}{c}\text { After } \\
\text { treatment }\end{array}$} & \multicolumn{2}{|c|}{ \pm to the first control } \\
\hline & & & pcs/plant & $\%$ \\
\hline Control (Standard chemical technology) & 8,6 & 3,2 & - & - \\
\hline Control 2 (Standard biological product Rizoplan) & 12,3 & 5,3 & 2,1 & 66 \\
\hline $\begin{array}{l}\text { Seed treatment with Nodix Premium, } 0.1 \mathrm{l} / \mathrm{t} \text { of seeds }+ \text { Nodix } \\
\text { Insectobact } 0.5 \mathrm{l} / \mathrm{t} \text { of seeds; Spraying in the bud phase with Nodix } \\
\text { Premium, } 0.3 \mathrm{l} / \mathrm{ha}+\text { Nodix Insectobact } 0.5 \mathrm{l} / \mathrm{ha} \text {; Spraying in the phase } \\
\text { of bud formation with Nodix Premium, } 0.11 / \mathrm{ha}\end{array}$ & 11,7 & 6,1 & 2,9 & 91 \\
\hline $\begin{array}{l}\text { Seed treatment with Nodix Premium, } 0.31 / \mathrm{t} \text { of seeds }+ \text { Nodix } \\
\text { Insectobact } 11 / \mathrm{t} \text { of seeds; Spraying in the bud phase with Nodix } \\
\text { Premium, } 0.31 / \text { ha }+ \text { Nodix Insectobact } 1.01 / \text { ha; Spraying in the } \\
\text { phase of bud formation with Nodix Premium, } 0.11 / \text { ha; Spraying in } \\
\text { the filling phase with Nodix Biofungicide } 1.01 / \text { ha }\end{array}$ & 10,8 & 4,0 & 0,8 & 25 \\
\hline $\begin{array}{l}\text { Seed treatment with Nodix Premium, } 0.51 / \mathrm{t} \text { of seeds }+ \text { Nodix } \\
\text { Insectobact } 11 / \mathrm{t} \text { of seeds; Spraying in the bud phase with Nodix } \\
\text { Premium, } 0.31 / \text { ha }+ \text { Nodix Insectobact } 2.01 / \text { ha; Spraying in the } \\
\text { phase of bud formation with Nodix Premium, } 0.11 / \text { ha }+ \text { Nodix In- } \\
\text { sectobact } 2.01 / \mathrm{ha} \text {; Spraying in the filling phase with Nodix } \\
\text { Biofungicide } 1.0 \mathrm{l} / \mathrm{ha}\end{array}$ & 9,1 & 3,3 & 0,1 & 3 \\
\hline
\end{tabular}


In the last option of the experiment, the effectiveness of processing the studied crop in the bud formation phase with Nodix Insectobact at the rate of 2 1/ha in combination with Nodix Premium (0.1 l / ha) is equivalent to the use of an insecticide, since the number of flower beetles decreases to 3.3 pcs/plant versus 3.2 in control.

According to the developers of Micro-box LLC, such a high efficiency of the biological product Nodix Insectobact against the most dangerous pests of spring rape is explained by the fact that when it enters the body of insects, it causes intestinal dysfunction, as a result of which the amount of food is reduced [11]. The toxin inhibits RNA synthesis in insect cells. Insects that have received a lethal dose of the pathogen die after different periods of time - from 2 to 3 days, depending on the size of the dose and the susceptibility of an individual. Insectobact in sublethal doses inhibits nutrition, disrupts the timing of metamorphosis, reduces the fertility of females and the viability of the next generations [12].
Such pests as rape sawflies, cabbage aphids, pods, beet nematodes live in very comfortable environment on crops of spring rapeseed in soil and climatic conditions. They are controlled by observing the recommended crop rotations, by placing it at a distance of $1.5-2.0 \mathrm{~km}$ from last year's crops, high-quality fall plowing, mowing of weeds along the edges of fields and providing an optimal nutritional background, including processing crops in the seed filling phase with such complex nutrient solutions as Nodix Premium containing easily digestible amino acids and chelated forms of micronutrients.

\section{Density and height of stems}

There is no doubt that the traditional system of protection of spring rape, based on the pre-sowing treatment of seeds with chemical dressing agents and repeated use of insecticides for the vegetation of plants, ensures the formation of a denser $\left(118 \mathrm{pcs} / \mathrm{m}^{2}\right)$ stem with an average plant height of $124 \mathrm{~cm}$ (Fig. 3), but significantly increases the chemical load on the environment.

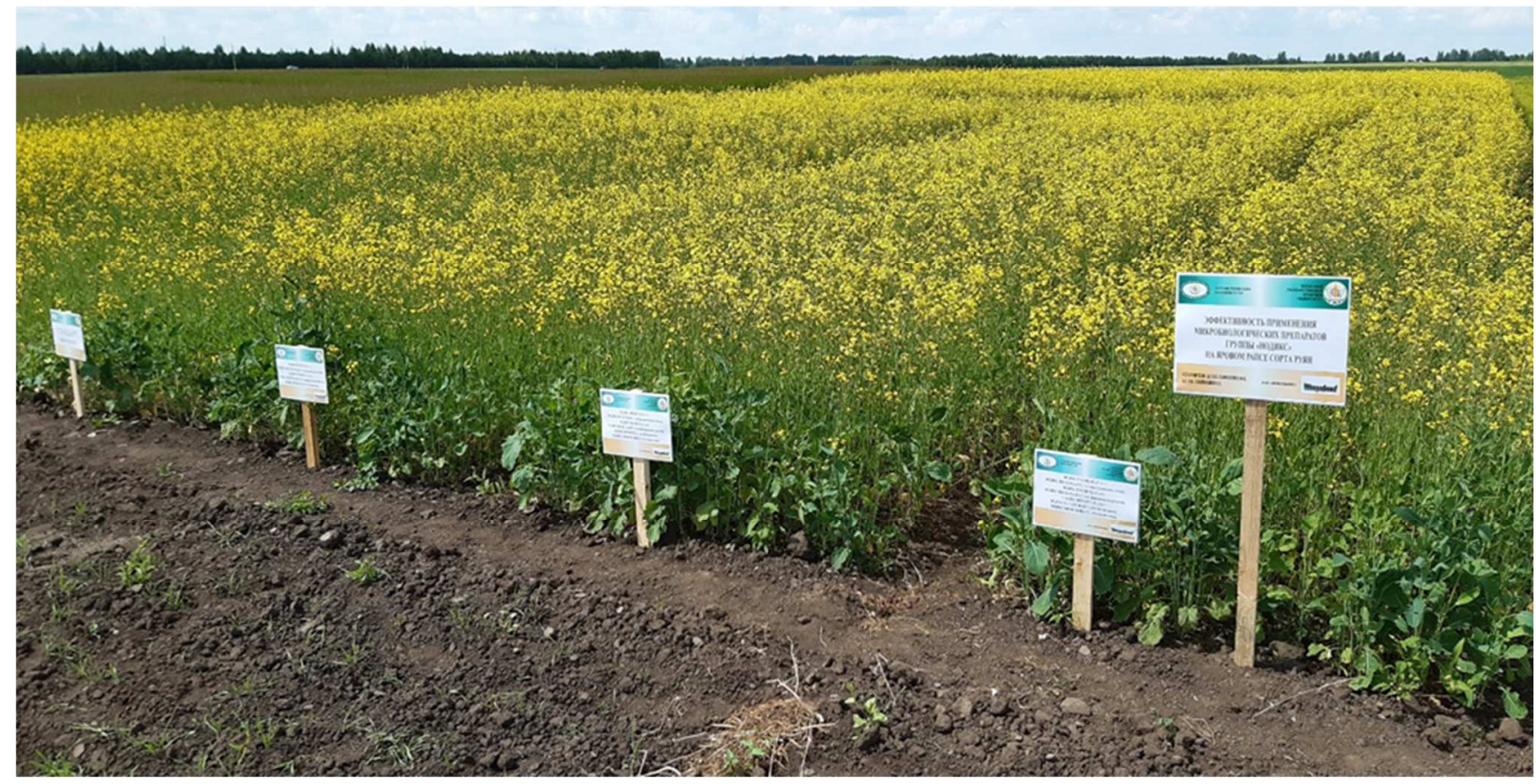

Fig. 3. General view of the experimental site

From this point of view, the most acceptable is the pre-sowing treatment of seeds with a working solution containing such bioinsecticides as Insectobact at the rate of $11 / t$ of seeds and additional treatment of crops during the growing season with the same bioinsecticide with the addition of Nodix Premium (0, 31 / ha). In this case a single treatment of spring rape against the cabbage moth with enteric-contact insecticide Break (70 g / ha) was sufficient against 3 -fold spraying of crops in the rape branching phase and a single treatment against the flower beetle at the beginning of plant bud formation.

At the same time, the difference in favor of chemical protection in terms of stand density and plant height was not large $-6 \mathrm{pcs} / \mathrm{m}^{2}$ and $4 \mathrm{~cm}$, respectively, but the savings in money amounted to about 3 thousand rubles/ha.
Productivity and gross yield of rapeseed oil. Three food products are characterized by sharp fluctuations in the selling price on the world market. These are buckwheat, granulated sugar and vegetable oil. Thus, by the fall of 2020, their retail price increased from 25 to 30 percent.

Such an unstable situation in the provision of the population with vegetable oil is primarily explained by sharp jumps in the yield of the main mass crop of the Republic of Tatarstan - spring rape due to the massive destruction of plants by certain pests, especially cabbage moth in recent years.

Therefore, research in this direction is of particular relevance and practical importance. Besides, the situation is complicated by the fact that the resistance of 
pests to chemical insecticides is increasing at an accelerated rate.

This is the reason why the studied biological system of protection of spring rapeseed from pests in terms of yield and gross yield of vegetable oil turned out to be almost on the same level as the chemical one (Table 3 ).

Table 3. Yield and gross yield of vegetable oil

\begin{tabular}{|c|c|c|c|}
\hline Option & $\begin{array}{c}\text { Productivity, } \\
\text { t/ha }\end{array}$ & $\begin{array}{l}\text { Crude fat } \\
\text { content, \% }\end{array}$ & $\begin{array}{l}\text { Gross } \\
\text { harvest of } \\
\text { vegetable } \\
\text { oil, } \mathrm{kg} / \mathrm{ha}\end{array}$ \\
\hline Control (Standard chemical technology) & 1,76 & 46,9 & 825,4 \\
\hline Control 2 (Standard biological product Rizoplan) & 1,15 & 47,8 & 549,7 \\
\hline $\begin{array}{l}\text { Seed treatment with Nodix Premium, } 0.1 \mathrm{l} / \mathrm{t} \text { of seeds }+ \text { Nodix } \\
\text { Insectobact } 0.5 \mathrm{l} / \mathrm{t} \text { of seeds; Spraying in the bud phase with Nodix } \\
\text { Premium, } 0.3 \mathrm{l} / \mathrm{ha}+\text { Nodix Insectobact } 0.5 \mathrm{l} / \mathrm{ha} \text {; Spraying in the phase } \\
\text { of bud formation with Nodix Premium, } 0.11 / \mathrm{ha}\end{array}$ & 1,34 & 46,9 & 628,5 \\
\hline $\begin{array}{l}\text { Seed treatment with Nodix Premium, } 0.31 / \mathrm{t} \text { of seeds }+ \text { Nodix } \\
\text { Insectobact } 11 / \mathrm{t} \text { of seeds; Spraying in the bud phase with Nodix } \\
\text { Premium, } 0.31 / \text { ha }+ \text { Nodix Insectobact } 1.01 / \text { ha; Spraying in the } \\
\text { phase of bud formation with Nodix Premium, } 0.11 / \text { ha; Spraying in the } \\
\text { filling phase with Nodix Biofungicide } 1.01 / \text { ha }\end{array}$ & 1,34 & 47,2 & 632,5 \\
\hline $\begin{array}{l}\text { Seed treatment with Nodix Premium, } 0.51 / \mathrm{t} \text { of seeds }+ \text { Nodix } \\
\text { Insectobact } 11 / \mathrm{t} \text { of seeds; Spraying in the bud phase with Nodix } \\
\text { Premium, } 0.31 / \text { ha }+ \text { Nodix Insectobact } 2.01 / \mathrm{ha} \text {; Spraying in the } \\
\text { phase of bud formation with Nodix Premium, } 0.11 / \text { ha }+ \text { Nodix In- } \\
\text { sectobact } 2.01 / \text { ha; Spraying in the filling phase with Nodix } \\
\text { Biofungicide } 1.0 \mathrm{l} / \mathrm{ha}\end{array}$ & 1,63 & 45,3 & 738,4 \\
\hline $\mathrm{LSD}_{05}$ & 0,22 & & \\
\hline
\end{tabular}

Thus, in the last option of the experiment with a biological protection system of the object of research, $1.63 \mathrm{t} / \mathrm{ha}$ of marketable oil raw materials with basic indicators of moisture (7\%), contamination (2\%), oil impurity $(6 \%)$ corresponding to acidic number to the first class $(2.2 \mathrm{mg} \mathrm{KOH})$ versus $1.76 \mathrm{t} / \mathrm{ha}$ in the standard option of the experiment. The difference in yield between the chemical and biological systems for the protection of spring rapeseed from pests is only $0.13 \mathrm{t}$ /ha and it can not be proven mathematically (LSD05 $0.22 \mathrm{t} / \mathrm{ha}$ ).

During the analysis of the content of crude fat in oilseed raw materials, it is impossible to ignore the existence of an inverse relationship between yield and oil content: the higher the first indicator, the lower the second. On the best options of the experiment (the first control and the last options), the best ones were the yields of 1.76 and $1.63 \mathrm{t} /$ ha, but a low content of crude fat was 46.9 and $45.3 \%$, respectively, against $47,8 \%$ on a low-yielding (1.05 t/ ha) second control option.

Nevertheless, in these options the highest gross yield of vegetable oil per unit area was noted. For example, the biological protection system of spring rape, based on pre-sowing seed preparation and three-fold treatment of crops with Insectobact, provided $738.4 \mathrm{~kg}$ of vegetable oil per hectare of arable land, which was only $10 \%$ lower than the first control option.

Consequently, the insignificant difference in the gross yield of vegetable oil between the chemical and biological systems for the protection of spring rapeseed from pests allows stating that the use of bioinsecticides such as Insectobact in combination with foliar feeding of plants Nodix Premium (0.3 l / ha) was very promising.

\section{Conclusion}

In order to reduce the chemical load on the environment, stabilize the production of ecologically safe rapeseed vegetable oil, it is necessary to pre-sow seed treatment with the Cruiser Rape seed disinfectant (15 1/t) to replace Insectobact $(11 / \mathrm{t})$ in combination with Nodix Premium (0.3 1/ta).

In order to protect spring rapeseed from pests during the growing season, 3 times treatment with Insectobact (2 $1 /$ ha) with the addition of a micro-nutrient biological product Nodix Premium (0.3 l / ha) is possible instead of 3-4 times spraying of crops with insecticides

The use of Nodix Biofungicide (1 1/ha) in the phase of rapeseed filling did not provide the expected result, since the plants most of all suffered from diseases at the initial stage of organogenesis.

\section{References}

1. F.N. Safiollin, R.M. Nizamov, V.M. Panasyuk, S.R. Suleymanov, A.A. Akhmetzyanov, BIO Web of Conferences, 17, 00241 (2020).

2. V.M. Lukomets, V.M. Penchukov, N.I. Zaitsev, Bulletin of the agro-industrial complex of Stavropol, 2, 85-87 (2015). 
3. B.N. Nasiev, A.S. Bushnev, Oilseeds, 4 (180), 45-49 (2019).

4. V.M. Lukomets, V.T. Piven, N.M. Tishkov, N.I. Bochkarev, S.A. Semerenko, Plant protection and quarantine, 6, 36-39 (2019).

5.D.T. Khaliullin, A.V. Dmitriev, Modern high technologies, 12-2, 272-276 (2015).

6. R.I. Safin, L.Z. Karimova, F.N. Safiollin, Sh.Z. Validov, B.G. Ziganshin, K.Z. Karimov,
G.S. Minnullin, E3S Web of Conferences, 91, 185193 (2019).

7. V.F. Moiseychenko et al., Fundamentals of scientific research in agronomy (Kolos, Moscow, 1996) 336 p.

8. V.M. Lukomets, N.M. Tishkov, V.F. Baranov, Methodology for conducting field agrotechnical experiments with oil crops (Krasnodar, 2010) 327 p.

9. B.A. Dospekhov, Methodology of field experience (Agropromizdat, Moscow, 1985) 351 p. 